\title{
QUALITY OF CORPORATE SOCIAL RESPONSIBILITY REPORTING (CSRR): THE INFLUENCE OF OWNERSHIP STRUCTURE AND COMPANY CHARACTERISTICS
}

\author{
Dalilawati Zainal
}

\begin{abstract}
The ongoing attention to corporate social responsibility reporting (CSRR) research is visible with most of the research focus on cross-sectional analysis and from the perspective of developed countries. Drawing upon the top publicly listed companies in Malaysia (a developing country's perspective), this study contributes to the extant CSRR literature by means of a longitudinal analysis of the influence of ownership structure and company characteristics on the quality of CSRR in both voluntary (year 2005) and mandatory (year 2009) CSRR regimes. The results from the regression analyses showed that companies with a higher proportion of family (government) ownership reported lower (higher) quality of CSRR in both the voluntary and mandatory reporting regimes. Companies with a higher proportion of foreign ownership disclosed a significantly greater quality of CSRR in the mandatory CSRR regime, yet no association was found between foreign ownership and CSRR quality during the voluntary CSRR regime. In terms of company-specific characteristics, company size and profitability are significantly positively related to CSRR quality in both reporting regimes; whereas the Shariah status of the company is only significantly related to CSRR quality in the voluntary reporting regime. Overall, to a certain extent, the above findings indicate the effect of CSRR regulation on the quality of CSRR.
\end{abstract}

Keywords: Corporate Social Responsibility Reporting, Regulation, Voluntary, Mandatory.

JEL Classification: M41, M48

\section{Introduction}

Many companies are blamed for causing environmental damage and social problems, and, consequently, environmental and social issues are on the rise. Among the global issues that need prompt attention are climate change, pollution, corporate scandals, and human rights (Crane, Matten, \& Spence, 2013). Malaysia, being a developing country that has undergone the continuous process of economic development and urbanization, is also confronted with these issues. For example, the findings of prior literature dictated that the

\footnotetext{
"Corresponding Author: Dalilawati Zainal, PhD is a Senior Lecturer in the Department of Accounting, Faculty of Business \& Accountancy, University of Malaya, 50603, Kuala Lumpur, Malaysia. Email: dalilawati@um.edu.my
}

This study is part of the research supported by BKP050-2014 research grant, University of Malaya. 
economic development of the country is related to a high level of energy consumption (Murad, Islam Molla, Mokhtar, \& Raquib, 2010), carbon dioxide emissions (Ang, 2008), and water pollution (Muyibi, Ambali, \& Eissa, 2008). One of the ways companies respond to these issues is through the implementation of corporate social responsibility (CSR), which is communicated in various media, such as corporate annual reports, websites, stand-alone reports, and social media.

In Malaysia, CSRR was a voluntary practice in companies prior to year 2007. Later, CSRR was made mandatory in the corporate annual report with effect from year 2007. Despite the regulation of Bursa Malaysia (formerly known as Kuala Lumpur Stock Exchange) on CSRR in companies' annual reports (Bursa Malaysia, 2007), there has been a lack of detailed reporting standards or guidelines for companies to follow. Hence, due to the freedom of companies to report CSR information in their own format, the stakeholders are at a disadvantage. By examining the quality of the CSRR disclosed, the assessment of the level of importance placed by companies in specific CSRR items or dimensions is made possible. One company may merely disclose descriptive CSR information indicating their general commitment towards CSR, while another company may provide more information by highlighting the costs and resources involved as well as the impact of the CSR activities performed. Responsible stakeholders prefer companies that exhibit a serious commitment to CSR, and, therefore, companies that disclose greater CSRR quality are able to attract more investors to invest in the companies and are endorsed by other stakeholders concerning their legitimacy or 'licence to operate'.

In addition, the stakeholders can play their role to exert pressure on companies to disclose CSRR, particularly when they control resources that are critical to the companies (e.g. shareholders, creditors) (Ullmann, 1985; Roberts, 1992; Huang \& Kung, 2010). Several company-specific characteristics (Adams, 2002; Gunardi, Febrian, Herwany, 2016; Habbash, 2016), such as company size and profitability, have also demonstrated mixed findings concerning their influence in determining the level of CSRR disclosed. Publicly listed companies in Malaysia are owned by a variety of shareholders, namely, family, foreign, and government shareholders. Many companies are also listed as Shariah-approved companys, indicating a company's commitment and compliance with the principles of Islamic teachings (e.g. social and environmental accountability, and full disclosure of information/transparency) (Baydoun \& Willett, 2000; Kamla et al., 2006). These unique features of companies in Malaysia have motivated the researcher to examine the influence of different types of ownership structure and company-specific characteristics, including a firm's Shariah status, as determinants of the CSRR quality from the perspective of a developing country. The idea for including the Shariah status of companies as one of the companyspecific characteristics that determine the quality of CSRR arises from the increasing importance of the Shariah-approved companies in Malaysia (Ousama \& Fatima, 2010) and the differences observed between reporting made by the Shariah and non-Shariah approved companies (Aribi \& Gao, 2010). 
Even though a number of researchers have examined the extent of CSRR, particularly from the perspective of developing countries (e.g. Khan et al., 2009; Elmogla et al., 2015) and the determinants of the levels of CSRR disclosed by companies (Hussainey et al., 2011; Gunardi et al., 2016), studies that focus on the quality of CSRR are rather limited (Ahmed Haji, 2013; Alotaibi \& Hussainey et al., 2016). The increasing trend of research on CSRR quality from the perspective of developed countries is apparent (Michelon et al., 2015; Ortas et al., 2015; Sethi et al., 2015; Habek \& Wolniak, 2016). With the imposition of CSRR regulation in Malaysia beginning in financial year 2007, it is of interest to investigate the determinants of CSRR quality in both the voluntary and mandatory CSRR regimes.

The findings from this study may serve as useful input for the relevant authorities to improve the implementation and enforcement of the existing regulations. Interested stakeholders may be informed of the types of company that disclose a greater quality of CSRR, which may denote the commitment of a company towards CSR. This study also highlights the importance of the Shariah status of companies in determining the quality of CSRR along with company size and profitability, particularly during the voluntary regime of CSRR. Section 2 reviews the related literature and highlights the relevant hypotheses developed for the purpose of this study. Section 3 explains the research methodology used, followed by a discussion of the findings gathered in section 4 . Finally, section 5 concludes the paper.

\section{Literature Review and Hypotheses Development}

CSRR refers to the reporting that is made by companies on issues that are important to a wide range of stakeholders, and that covers more than solely economic concerns (Jenkins et al., 2006). In this study, CSRR encompasses five dimensions, namely, environmental, community, workplace, marketplace, and others. Details on the CSRR dimensions are discussed in the research methodology section. Empirical studies that examined the level of CSRR mostly measure CSRR in terms of indices, words, sentences, paragraphs, and pages, etc., without recognizing the relative usefulness of certain types of CSR information to readers (Hook \& Van Staden, 2011). By examining the quality of CSRR, the level of importance placed by companies on the CSRR disclosed can be identified (Freedman \& Jaggi, 2005; Joseph \& Taplin, 2011).

Hasseldine et al. (2005), who examined the impact of environmental disclosure on the reputation of UK companies, found that the quality of environmental disclosure has higher explanatory power (in terms of $\mathrm{R}^{2}$ ) than the quantity of environmental disclosure in explaining the variation in the reputation of companies in the UK. Joseph and Taplin (2011), who analysed the CSRR disclosed on the Malaysian local government websites, also observed similar evidence. Joseph and Taplin suggested that the CSRR quality is a more predictable measurement of CSRR, as evidenced by a greater explanatory power 
and more significant independent variables produced in the hypothesized relationship between several independent variables and the CSRR.

The quality of CSRR refers to the quality of reporting made on a particular CSRR item listed in the CSRR index (Joseph \& Taplin, 2011). It captures the variety of CSRR disclosed by companies (Haniffa \& Cooke, 2005) and indicates the importance (or weight) given to a particular CSRR item relative to other items (Freedman \& Jaggi, 2005; Hooks \& Van Staden, 2011; Joseph \& Taplin, 2011). It also aims to distinguish between the poor and excellent reporting of the CSRR items (Hooks \& Van Staden, 2011).

The growing popularity of CSRR research that examined the quality of CSRR is clear (Ahmed Haji, 2013; Ortas et al., 2015; Sethi et al., 2015; Alotaibi \& Hussainey, 2016; Habek \& Wolniak, 2016). For example, Ahmed Haji (2013) investigated the factors that influence CSR disclosure before and after the financial crises and regulatory changes (date set of years 2006 and 2009) in Malaysia based on a small sample of companies ( 85 companies). Ahmed Haji (2013) found a significant positive association between company size and CSR disclosure quality in both year 2006 and year 2009, whereas government ownership only showed a significant positive association with CSR disclosure quality in year 2006, which was before the financial crises and regulatory changes.

In a wider perspective, Ortas et al. (2015) analysed the influence of companies' financial factors on the quality of corporate environmental sustainability reporting in a sample of 3931 companies in 59 countries (inclusive of 40 companies in Malaysia). According to Ortas et al. (2015), company size and profitability have more effect on companies with a higher commitment to disclose environmental sustainability information. Within the context of the European Union (EU) countries, Habek and Wolniak (2016) highlighted the differences in the quality of CSRR in both the voluntary and mandatory reporting regimes. The findings from Habek and Wolniak (2016) suggested that the legal obligation of CSR data disclosure has a positive effect on the quality of CSR reports (based on 507 CSR reports). Focusing on the world's largest financial institutions in year 2012, Sethi et al. (2015) revealed that the legal factors and CSR environment in a company's country of headquarters have a significant impact on the variations in the quality and comprehensiveness of CSRR published (based on 104 CSR reports). Alotaibi and Hussainey (2016), who studied the determinants of the quantity and quality of CSRR in the Saudi Arabian context, argued that both measurements of CSRR carry different drivers/determinants.

Following the greater emphasis on the quality of CSRR, this study examines the determinants of CSRR quality in a developing country, namely, Malaysia. The uniqueness of the corporate ownership structure in the Asian countries, including Malaysia, that are mostly family- and government-owned (Ball et al., 2003; Jaggi et al., 2009), has attracted researchers to investigate the influence of different types of ownership structure on the level of corporate reporting, particularly CSRR. For example, Haniffa and Cooke (2005), and Ghazali (2007) 
examined the influence of the corporate ownership structure on the level of voluntary CSRR in Malaysia. Later, Ahmed Haji (2013) conducted a small-scale study to determine the factors that influence the quality of CSRR before and after the financial crises and regulatory changes in Malaysia. Therefore, this study extends the work of Ahmed Haji (2013) by examining the effect of corporate ownership structure (namely, family, foreign, and government ownership) and company-specific characteristics (namely, company size, profitability, and Shariah status) on the quality of CSRR disclosed in a longitudinal setting (voluntary CSRR regime: year 2005; mandatory CSRR regime: year 2009). Using a more comprehensive classification of the corporate ownership structure and CSRR checklist, a larger sample size, different data set/sample time frame, and additional company-specific characteristic (e.g. Shariah status), this study expects some variation in the findings compared to the findings of Ahmed Haji (2013).

In contrast to Ahmed Haji (2013), who adopted multiple theories (legitimacy, agency, and signalling theories), this study applies the stakeholder theory, whereby companies are expected to respond to the multiple stakeholder groups, especially those that are powerful and can impact significantly on the companies (Ullmann, 1985; Huang \& Kung, 2010). Based on the model of determinants of CSR disclosure by Roberts (1992), shareholder power is proposed to be one of the determinants of CSR disclosure. The extant CSRR literature that adopted the stakeholder theory seems to classify shareholders as either concentrated or diffused ownership, which is very much relevant to the corporate ownership characteristics of Western developed countries. Since this study focuses on the perspective of a developing country within the Southeast Asian region, the extension of the classification of shareholders that includes family, foreign, and government ownership is considered appropriate to reflect the unique corporate ownership structure in the country.

Family companies are characterised by the founding family's concentrated ownership or the founding family members' active involvement in the companies' management, either as top executives or directors (Chen et al., 2008; Wan-Hussin, 2009). Being involved with the companies' management, the family owners have greater access to internal information compared to other shareholders, such as non-family and minority shareholders. The presence of family members on the board of directors also indicates the existence of a dominant group that may strongly influence the board's decisions on corporate disclosure (Chen et al., 2008). In this case, there is less reliance of the family owners on public disclosure, which leads to the lower demand for public disclosure in family-owned/controlled companies (Haniffa \& Cooke, 2005). However, studies that documented greater disclosure quality in family companies, for example, Chen et al. (2008), and Wan Hussin (2009) argued about the benefits of such disclosure, such as reduced cost of capital and the cost of withholding bad news. Chen et al. (2008) documented a higher likelihood of earnings warnings in family companies, and Wan Hussin (2009) reported greater transparency of the family companies in Malaysia. Habbash (2016) also found a 
positive association between family ownership and the CSRR disclosed in Saudi companies after the introduction of the Saudi Corporate Governance Code in year 2007.

Prior studies that examined CSR in family companies documented different effects of family ownership across various CSR dimensions (Block \& Wagner, 2014; Campopiano \& De Massis, 2015). Although family ownership is negatively associated with community-related CSR, it is positively associated with diversity, employees, the environment, and the product-related aspects of CSR (Block \& Wagner, 2014). Campopiano and De Massis (2015), who conducted a content analysis of the CSR reports of 98 large and medium-sized Italian companies, also highlighted the poorer compliance of family companies with CSR standards. Similarly, El-Ghoul et al. (2016) indicated lower CSR performance in family-controlled companies based on data collected in nine East Asian economies.

In terms of CSRR in Malaysia, family companies may have less motivation to disclose a greater quality of CSRR during the voluntary reporting regime. Nevertheless, they are expected to improve their reporting quality following the introduction of CSRR regulation, beginning from year 2007. By disclosing a greater quality of CSRR, family companies may demonstrate their compliance with the reporting regulation as well as reduce the likelihood of stricter regulation imposed in the future. Therefore, this study hypothesizes:

Hla: Companies with a higher proportion of family ownership reported a lower quality of CSRR in the voluntary reporting regime.

Hlb: Companies with a higher proportion of family ownership reported a higher quality of CSRR in the mandatory reporting regime.

Following the increase in the activities of the Western businesses in the Asian region, the current trends of CSR implementation in many Asian countries have been largely influenced by the Western-style of CSR practices (Chapple \& Moon, 2005). As argued by Ali et al. (2017), CSR reporting in developing countries is very much influenced by the external forces/powerful stakeholders, which, among others, include foreign investors. The influence of foreign shareholders, especially those from Europe and North America, whereby CSR is seen as desirable (Gugler \& Shi, 2009), has been apparent due to their familiarity with social issues and greater emphasis on CSR in their home countries (Oh et al., 2011). In this case, increased disclosure or CSR engagement may function as an important signalling mechanism to reduce the information asymmetry problem between the foreign shareholders and the managers of the company (Oh et al., 2011). Compared with the local shareholders, the foreign shareholders tend to have different investment preferences and time horizons. They prefer to invest in companies about which they are well informed and avoid companies with low disclosure (Mangena \& Tauringana, 2007). Companies need to disclose more information than the minimum requirements of the stock exchange in order 
to compete in international capital markets (Meek \& Gray, 1989). The findings by $\mathrm{Oh}$ et al. (2011) revealed a positive association between foreign ownership and CSR rating in Korea. Similarly, McGuinness et al. (2017) also documented an increase in the CSR scores with the level of foreign corporate ownership in China.

Past CSRR research in Malaysia documented mixed findings (positive association: Haniffa \& Cooke, 2005; no association: Amran \& Devi, 2008; Said et al., 2009) for the foreign ownership-CSRR relationship. According to Amran and Devi (2008), foreign-owned companies may use other reporting media, such as stand-alone reporting and websites to disclose their CSRR other than the corporate annual reports. Drawing upon the argument of Amran and Devi (2008), this study hypothesizes no association between foreign ownership and CSRR quality during the voluntary regime of CSRR. However, a positive association is expected when CSRR becomes mandatory to demonstrate compliance with the reporting regulation imposed. Failure to comply may mean that companies are confronted by negative consequences, such as penalties and bad reputation. Therefore, this study hypothesizes:

H2a: $\quad$ There is no association between foreign ownership and the quality of CSRR in the voluntary reporting regime.

H2b: Companies with a higher proportion of foreign ownership reported a higher quality of CSRR in the mandatory reporting regime.

Government ownership in companies can be described by the percentage of ownership and controls possessed by the government in a particular company. Generally, the government is interested in investing in companies that are of strategic importance to the country. Companies in which some of their shares are controlled by the government are commonly known as 'government-linked companies' or GLCs (Feng et al., 2004). Operating like other companies with commercial objectives, the goals of GLCs that relate to the interest of the nation may be in conflict with their profit-making goal (Mak \& Li, 2001). Consequently, this conflict may affect the level of disclosure made by the GLCs (Eng \& Mak, 2003). Government ownership may create a certain level of pressure on companies to provide more information to the public, owing to the accountability of the government to serve the interests of the nation.

In relation to CSRR, Habbash (2016) reported a positive association between government ownership and CSRR based on sample-companies (data set for the year 2007-2011) in the Saudi Arabian context. However, Alotaibi and Hussainey (2016), who used a data set for 2013 and 2014, found a negative association between government ownership and CSRR quantity, and no association between government ownership and CSRR quality in the same context. Prior evidence in the Malaysian context indicated a positive association between government ownership and CSRR (Ghazali, 2007; Amran \& Devi, 2008). By having a high proportion of shares held by the government and senior 
government officers sitting on the board, the government-owned companies are in a good position to influence the disclosure policies that, in most cases, support the initiatives outlined by the government policies. For example, the concerns of the Malaysian government about many of the CSR issues have been made apparent with a number of significant initiatives being undertaken. Among others, these include the CSRR framework for publicly listed companies, CSR guidelines for GLCs, and tax incentives for companies that undertake CSRrelated activities. Subsequently, CSRR was made mandatory for all publicly listed companies in Malaysia beginning 2007. Moving forward, Sustainability Reporting (SR) guidelines and SR reporting requirements were mandated at the end of year 2016. Perhaps, a renewed effort that relates government ownership to the quality of CSRR specifically after the CSRR regulation took place may dictate the way companies react to the implementation of the regulation. Since government-owned companies are expected to report a higher quality of CSRR due to their accountability to society as a whole, it is expected that there will be no change in the firm's behaviour subsequent to the implementation of CSRR regulation. Therefore, this study hypothesizes:

H3a: Companies with a higher proportion of government ownership reported a higher quality of CSRR in the voluntary reporting regime.

H3b: $\quad$ Companies with a higher proportion of government ownership reported a higher quality of CSRR in the mandatory reporting regime.

Several company-specific characteristics have also influenced the level of CSRR; for example, company size and profitability (Gunardi et al., 2016; Habbash, 2016). Companies that are larger in size and more profitable have greater public visibility and impact on society, and, thus, they are more likely to use CSRR to respond to public pressure (Fifka, 2013; Hahn \& Kuhnen, 2013; Ali et al., 2017). This study also introduces the Shariah status of the company as one of the determinants of CSRR quality, in addition to size and profitability. Shariah-approved companies refer to those that conduct activities as permitted by Shariah (the Islamic law of human conduct) and have been approved by the Shariah Advisory Councils (SAC). These companies are expected to be more environmentally and socially responsible and disclose a greater quality of CSRR (Zainal et al., 2013); based on the grounds that the Islamic teachings promote the concept of social accountability and the principle of full disclosure (Baydoun $\&$ Willett, 2000). Many principles of the Islamic teachings are also related to the concept of CSR; for example, accountability, equality, and social justice (Kamla et al., 2006). To a certain extent, the justifications underpinning social and environmental accounting, of which CSRR is a part, are parallel to Islamic accounting, which is governed by Islamic values and its economic system (Zulkifli 2012). Regardless of the existence of specific reporting regulation, larger, profitable, and Shariah-approved companies are expected to disclose a greater quality of CSRR. Therefore, this study hypothesises: 
Quality of Corporate Social Responsibility Reporting (CSRR): The Influence of Ownership Structure and Company Characteristics

H4: Larger companies reported a higher quality of CSRR in both the voluntary and mandatory reporting regimes.

H5: $\quad$ Companies with higher profit reported a higher quality of CSRR in both the voluntary and mandatory reporting regimes.

H6: $\quad$ Shariah-approved companies reported a higher quality of CSRR in both the voluntary and mandatory reporting regimes.

\section{Research Methodology}

This study uses a sample of 180 publicly listed companies (listed on Bursa Malaysia, formerly known as Kuala Lumpur Stock Exchange) from year 2005 and 2009. The sample companies are drawn from the top 300 companies by market capitalization for both years. The selection of top companies is in line with the argument that larger companies have greater public visibility, and, thus, are more likely to use CSRR to respond to public pressure (Branco \& Rodrigues, 2008). These companies also possess a greater amount of resources to be allocated to CSR-related activities. The sample is considered appropriate and sufficient, even larger than the sample included in several prior studies; see, for example, Ahmed Haji (2013) and Sethi et al. (2016).

Unlike cross-sectional data, the longitudinal data employed in this study (data set: year 2005 and 2009) allow the researcher to demonstrate the consistency of the findings revealed over a specified period. Year 2005 represents the voluntary regime of CSRR, whereas year 2009 denotes the mandatory CSRR regime. CSRR was practiced on a voluntary basis in year 2005; hence, some variation in the determinants of CSRR is expected in comparison with the reporting made during the year 2009, whereby, to a certain extent, every company was expected to disclose CSR information due to the mandatory reporting requirement. Prior longitudinal CSRR analyses conducted in different countries documented some variation in both the quality of CSRR disclosed and its determinants (Ahmed Haji, 2013; Alotaibi \& Hussainey, 2016; Habbash, 2016). Drawing upon the stakeholder theory, this study examines the effect of different shareholders' power and several company-specific characteristics on the quality of CSRR in Malaysia during pre- and postmandatory CSRR requirements. The data used for the purpose of this research were collected manually from the companies' annual reports. Table 1 summarises the research variables used in this study.

Table 1. Summary of the Measurement of the Research Variables

\begin{tabular}{ll}
\hline Variables Acronym & Measurement \\
\hline $\begin{array}{l}\text { Dependent variables } \\
\text { CSRR Quality CSRRQL }\end{array}$ & $\begin{array}{l}\text { CSRR index (based on a weighted scoring method) that is } \\
\text { computed by the ratio of actual score of CSRR awarded to } \\
\text { the maximum score of CSRR attainable by the company. } \\
\text { Refer to Appendix for the checklist of the CSRR index. }\end{array}$
\end{tabular}


Table 1. Summary of the Measurement of the Research Variables (continued)

\begin{tabular}{|c|c|c|}
\hline \multicolumn{3}{|c|}{ Independent variables } \\
\hline Family Ownership & FAMOWN & $\begin{array}{l}\text { Percentage of family members on board to total number of } \\
\text { directors on the board }\end{array}$ \\
\hline $\begin{array}{l}\text { Foreign } \\
\text { Ownership }\end{array}$ & FOROWN & $\begin{array}{l}\text { Percentage of shares held by foreign shareholders to total } \\
\text { number of shares issued }\end{array}$ \\
\hline $\begin{array}{l}\text { Government } \\
\text { Ownership }\end{array}$ & GOVOWN & $\begin{array}{l}\text { Percentage of shares held by government to total number of } \\
\text { shares issued }\end{array}$ \\
\hline Company size & SIZE & Natural log of total assets \\
\hline $\begin{array}{l}\text { Company } \\
\text { Profitability }\end{array}$ & PROFIT & Return on assets \\
\hline $\begin{array}{l}\text { Company Shariah } \\
\text { Status }\end{array}$ & SHARIAH & $\begin{array}{l}\text { Dichotomous with } 1 \text { if the company is listed as a Shariah- } \\
\text { approved company and } 0 \text { if otherwise. }\end{array}$ \\
\hline
\end{tabular}

This study uses the weighted scoring method to measure the quality of CSRR over the dichotomous scoring method, owing for the advantages that this method offers (e.g. simple, less controversial, and ability to indicate the level of emphasis) (Freedman \& Jaggi, 2005). In line with the weighted scoring method, the score of each CSR-related item disclosed is measured by assigning a score of 3 (if there is quantitative disclosure - highest weight); 2 (if there is qualitative specific information); 1 (if there is general qualitative disclosure - lowest weight); and 0 (if there is no disclosure). A similar scoring method was adopted in the study of Ahmed Haji (2013).

As an example, one item - education - from the community dimension of the CSRR checklists used to illustrate the assignment of value using the weighting procedure in the content analysis.

A score of 3 is given for reporting that contains quantitative information: "TNB through its foundation, Yayasan Tenaga Nasional (YTN) provided scholarships and study loans amounting to RM34.6 million to 2,478 outstanding and deserving students to pursue their tertiary education at local and world renowned universities abroad. This is a direct contribution towards the development of professional manpower for TNB and the Country. Since its inception in 1993, YTN has provided education sponsorship to more than 8,820 students."

A score of 2 is given for reporting with qualitative specific information: "38 students received the Young Achievers' Award from Yayasan Tan Sri Lee Shin Cheng ("Yayasan") at Palm Garden Hotel, IOI Resort. Various awards from primary to upper secondary levels namely UPSR, PMR, SPM, STPM and Alevels are distributed to young students to motivate them to strive for excellence in their studies."

A score of 1 is given for reporting that contains general qualitative information: "Our contribution towards education can best be described as wide-ranging. In support of national schools and national-type vernacular schools located in the Group's Malaysian estates and property townships, the Group has made contributions in the form of land for the school premises as 
well as regular donations in cash and kind to meet the varied needs of the schools and their students."

Based upon the illustration given, this study assumes that a higher reporting weight (based on a score between 0 and 3 ) demonstrates greater emphasis placed by companies on the specific CSRR item, relative to a lower reporting weight. For example, a CSRR item with a score of 3 indicates a greater emphasis placed by companies on that particular CSRR item, while a CSRR item with a score of 1 indicates otherwise. A higher score obtained for a specific CSRR item also denotes a better quality of reporting on that particular item. The reliability of a CSRR quality measurement of .862, based on the Cronbach's coefficient alpha, indicates an acceptable level of reliability (minimum of .80). The development of the CSRR checklist is based on the references made to a list of prior CSRR literature (e.g. Hackston \& Milne, 1996; Haniffa \& Cooke, 2005; Maali et al., 2006; Kamla, 2007; Ahmed Haji, 2013) and reporting guidelines, such as Global Reporting Initiative (GRI), Sustainability Reporting Guideline, and Bursa Malaysia's CSR Framework for Malaysian companies. To examine the determinants of CSRR quality, this study runs regression analysis using the SPSS software based on the following model:

$$
\begin{aligned}
\text { CSRRQL }_{i t}= & \beta_{0}+\beta_{1} \text { FAMOWN }_{i t}+\beta_{2} \text { FOROWN }_{i t}+\beta_{3} \text { GOVOWN }_{i t}+\beta_{4} \text { SIZE }_{i t}+ \\
& \beta_{5} \text { PROFIT }_{i t}+\beta_{6} \text { SHARIAH }_{i t}+\varepsilon_{i t}
\end{aligned}
$$

where, CSRRQL is CSRR Quality; FAMOWN is Family Ownership; FOROWN is Foreign Ownership; GOVOWN is Government Ownership; SIZE is Company Size; PROFIT is Company Profitability; SHARIAH is Company Shariah Status. All the assumptions of the regression analysis (normality, multicollinearity, linearity, and homoscedasticity) are met before the analysis is performed.

\section{Results and Discussion}

Table 2 presents the descriptive statistics of the research variables used in this study for the years 2005 (voluntary CSRR regime) and 2009 (mandatory CSRR regime). As shown in Table 2, the mean of the quality of CSRR increases from .105 in 2005 to .191 in 2009 . The results also indicate that all the sample companies report at least minimum CSR information (min. 2005: .010; 2009: .040 ) in the annual reports. While there has been a slight increase in the mean of family ownership, foreign ownership, government ownership, company size, and the number of Shariah-approved companies from year 2005 to 2009, the mean for company profitability slightly reduced. 
Table 2. Descriptive Statistics of the Research Variables

\begin{tabular}{lllll}
\hline 2005 $(\mathbf{N}=180$ companies) & Mean & Std. Dev. & Min. & Max. \\
\hline CSRRQL & .105 & .087 & .010 & .400 \\
FAMOWN & 16.800 & 21.500 & .000 & 67.000 \\
FOROWN & 22.147 & 21.140 & .220 & 83.590 \\
GOVOWN & 11.920 & 17.010 & .000 & 8.130 \\
SIZE & 7.566 & 1.418 & 5.200 & 12.160 \\
PROFIT & .060 & .066 & -.270 & .350 \\
& Shariah Status $(1)$ & Shariah Status $(0)$ \\
Company Shariah Status & 127 & & 53 & \\
& & & & \\
$\mathbf{2 0 0 9}(\mathbf{N}=\mathbf{1 8 0}$ companies) & Mean & Std. Dev. & Min. & Max. \\
\hline CSRRQL & .191 & .104 & .040 & .600 \\
FAMOWN & 17.100 & 21.500 & .000 & 75.000 \\
FOROWN & 24.230 & 21.945 & .000 & 85.500 \\
GOVOWN & 12.289 & 16.274 & .000 & 82.230 \\
SIZE & 7.944 & 1.407 & 5.240 & 12.640 \\
PROFIT & .053 & .083 & -.470 & .520 \\
Company Shariah Status & Shariah Status (1) & Shariah Status (0) \\
\hline
\end{tabular}

Table 3 presents the multiple regression analysis results for both years of analysis (2005 and 2009) that indicates the determinants of CSRR quality. The F-value for each year's data is statistically significant at the 1 per cent level. The adjusted $\mathrm{R}^{2}$ indicates that the model explains $30.9 \%$ of the variance in CSRR's quality during the voluntary CSRR regime and $34.4 \%$ during the mandatory regime.

Table 3. Multiple Regression Analysis

\begin{tabular}{|c|c|c|c|c|}
\hline \multirow[t]{2}{*}{ Variables } & \multicolumn{2}{|c|}{$\begin{array}{l}2005 \\
\text { (Voluntary Reporting) }\end{array}$} & \multicolumn{2}{|c|}{$\begin{array}{l}2009 \\
\text { (Mandatory Reporting) }\end{array}$} \\
\hline & Coef. & $t$-Stat. & Coef. & $t$-Stat. \\
\hline FAMOWN & -.288 & $-4.365 * * *$ & -.162 & $-2.453 * *$ \\
\hline FOROWN & .070 & 1.003 & .142 & $2.159 * *$ \\
\hline GOVOWN & .222 & $3.309 * * *$ & .222 & $3.254 * * *$ \\
\hline SIZE & .355 & $4.979 * * *$ & .435 & $6.172 * * *$ \\
\hline PROFIT & .228 & $3.265 * * *$ & .215 & $3.326 * * *$ \\
\hline SHARIAH & .165 & $2.487 * *$ & .087 & 1.334 \\
\hline Constant & -.101 & $-2.592 * * *$ & -.112 & $-2.218 * *$ \\
\hline Adjusted R2 & $.309 * * *$ & & $.344 * * *$ & \\
\hline F-Value & 14.343 & & 16.624 & \\
\hline $\mathrm{N}$ & 180 & & 180 & \\
\hline
\end{tabular}

As shown in table 3, companies with a higher proportion of family ownership disclose a significantly lower quality of CSRR in both the voluntary and mandatory reporting regimes, whereas companies with a higher proportion of government ownership dictate otherwise. The results provide support for H1a, $\mathrm{H} 3 \mathrm{a}$, and $\mathrm{H} 3 \mathrm{~b}$. The findings partly demonstrate the need for improvement in terms of the regulatory aspect, for example, enforcement and monitoring. As expected, family companies disclosed lower quality CSRR during the voluntary 
reporting regime due to their being less concerned about CSR (Haniffa \& Cooke, 2005; Ghazali, 2007). This finding also concurs with the argument of El-Ghoul et al. (2016) concerning the lower CSR performance of family-controlled companies in East Asian economies.

In contrast to the proposed hypothesis (H1b) and evidence concerning companies' compliance with the regulations (Criado-Jimenez et al., 2008; Habbash, 2016), this study showed a negative association between family ownership and CSRR quality during the mandatory CSRR regime. Hence, H1b is not supported. This is in agreement with the finding of Campopiano and De Massis (2015) who reported that family companies were less compliant with the CSR standards. Perhaps, further discussion and research should be undertaken at the regulatory authority-company level to enhance the quality of CSRR, which may benefit the readers, especially for the existing and potentially socially responsible investors.

Government-owned companies have indicated their support for the government's efforts to promote CSR by maintaining a good quality of CSRR in both the voluntary and mandatory reporting regimes. This study provides additional support to the extant literature that found a positive association between government ownership and CSRR in the voluntary and mandatory reporting regimes (Ahmed Haji, 2013; Habbash, 2016). The CSRR practiced by the government companies should be seen as exemplary for other companies to follow, perhaps as best practices. Apart from their role to serve the society, the availability of the CSR Silver Book for GLCs as reporting guidelines may partly assist the government-owned companies to report a better quality of CSRR.

Even though foreign ownership had no association with the quality of CSRR during the voluntary reporting regime (Amran \& Devi, 2008; Said et al., 2009), a significant positive association (Haniffa \& Cooke, 2005) is found during the mandatory reporting regime. Hence, $\mathrm{H} 2 \mathrm{a}$ and $\mathrm{H} 2 \mathrm{~b}$ are supported. As argued by Amran and Devi (2008), foreign-owned companies tended to use other media to report their CSR activities during the voluntary reporting regime, for example, stand-alone reports and websites. The lack of reporting regulation prior to 2007 may also hinder the development of the quality of CSRR (CriadoJimenez et al., 2008). In comparison, during the mandatory reporting regime, these companies have shown their adherence to the regulation imposed by disclosing a significantly greater quality of CSRR. Perhaps, this strategy is also taken to partly avoid future stricter reporting regulation imposed by the Malaysian government. To a certain extent, the findings of the study are consistent with Oh et al. (2011), and McGuinness et al. (2017), who indicated a positive association between foreign ownership and CSR performance in Korea and China, respectively.

In summary, different types of ownership structure have a different impact on the quality of the CSRR disclosed. Serving a variety of interests (e.g. family, foreign, and government shareholders), the regulatory authorities (e.g. Securities Commission, Bursa Malaysia) should play an active role in promoting sustainability in Malaysia, whereby CSR is a part thereof. Not only setting up 
the regulations, the authorities are expected to continuously educate the companies concerning the awareness, importance or benefits of CSR and CSRR, to provide support to those needed, etc. Regular discussions between the parties involved may facilitate the process towards the better implementation of CSR activities in companies as well as achieving a greater quality of CSRR.

Besides the different types of corporate ownership structure, several company-specific characteristics also influenced the quality of CSRR disclosed. As indicated in Table 3, company size and profitability indicated a positive association with the quality of CSRR, while the Shariah status of a company only showed significant positive association with the quality of CSRR during the voluntary regime. Based on the hypotheses developed, $\mathrm{H} 4$ and $\mathrm{H} 5$ are supported, while H6 is partially supported (e.g., during the voluntary reporting regime). The results indicated that large and profitable companies tend to disclose a significantly greater quality of CSRR, even in the absence of the reporting regulation (Fifka, 2013; Hahn \& Kuhnen, 2013; Gunardi et al., 2016; Habbash, 2016; Ali et al., 2017). As these companies are in the public limelight, CSRR may assist them in maintaining their good reputation and image, as well as demonstrate their accountability to the stakeholders.

Shariah-approved companies also provide better quality CSRR during the voluntary regime to exhibit their serious commitment towards CSRR, in line with the relevant concepts of Islam (e.g. accountability and full disclosure) (Baydoun \& Willet, 2000; Kamla et al., 2006). However, its role diminished following the mandatory CSRR regime. The introduction of CSRR regulation beginning from year 2007 may discourage the Shariah-approved companies to further improve their quality of CSRR disclosed. These companies may be motivated to adhere to the reporting requirement as provided by the Bursa Malaysia CSR Framework, or Bursa Malaysia Sustainability Reporting guideline beginning financial year 2016, which is found to lack detailed reporting guidelines. The absence of an appropriate and sufficient reporting guideline or standard may hinder further development of CSRR, as many companies are working towards compliance with the regulation imposed. It is undeniable that several companies are willing to disclose a greater quality of CSRR, beyond what is required by the regulation. However, their number is minimal. Perhaps, the relevant authorities should put more effort into educating the companies about the importance and benefit of good quality CSRR, so that the companies are more motivated to improve their reporting quality.

\section{Conclusion}

This study examines the determinants of CSRR quality under two different reporting regimes - voluntary and mandatory reporting - from a developing country's perspective, namely, Malaysia. In general, the findings of the study indicate the different impacts of different types of corporate ownership structure (e.g. family, foreign, and government ownership) and several company-specific characteristics (e.g. company size, profitability, and Shariah status) on the 
quality of CSRR during the voluntary and mandatory reporting regimes. There have been calls for several enhancement efforts to be undertaken by the relevant authorities (e.g. Securities Commission, Bursa Malaysia, Putrajaya Committee on GLC High Performance, Khazanah Nasional Berhad) to increase the level of companies' awareness about CSR and CSRR, perhaps through continuous campaigns, educational workshops, and support systems, which will motivate companies to produce a better quality of CSRR. To a certain extent, high-quality CSRR indicates the strong commitment of companies towards sustainability. It also provides meaningful information for investors in making their investment decisions; and to other stakeholders, especially those socially responsible stakeholders to be informed about the companies' sustainability performance. Being informed about the current development of CSRR, the management of companies and preparers of the CSRR should also benefit from these findings as inputs to further improve the existing CSRR practice. For example, the lower CSRR observed in family companies, even in the mandatory CSRR regime, may motivate the companies to improvise the current status of CSRR to portray the active roles of their companies in support of sustainability. After all, it is the responsibility of everyone to ensure the sustainability of the planet and society to benefit future generations.

\section{References}

Adams, C. A. (2002). Internal organisational factors influencing corporate social and ethical reporting: Beyond current theorising. Accounting, Auditing \& Accountability Journal, 15(2), 223-250.

Ahmed Haji, A. (2013). Corporate social responsibility disclosures over time: evidence from Malaysia. Managerial Auditing Journal, 28(7), 647-676.

Ali, W., Frynas, J. G., \& Mahmood, Z. (2017). Determinants of Corporate Social Responsibility (CSR) Disclosure in Developed and Developing Countries: A Literature Review. Corporate Social Responsibility and Environmental Management, 24(4), 273-294.

Alotaibi, K. O., \& Hussainey, K. (2016). Determinants of CSR disclosure quantity and quality: Evidence from non-financial listed firms in Saudi Arabia. International Journal of Disclosure and Governance, 13(4), 364393.

Amran, A., \& Devi, S. S. (2008). The impact of government and foreign affiliate influence on corporate social reporting: The case of Malaysia. Managerial Auditing Journal, 23(4), 386-404.

Ang, J. B. (2008). Economic development, pollutant emissions and energy consumption in Malaysia. Journal of Policy Modeling, 30, 271-278.

Aribi, Z. A., \& Gao, S. (2010). Corporate social responsibility disclosure: A comparison between Islamic and conventional financial institutions. Journal of Financial Reporting and Accounting, 8(2), 72-91. 
Ball, R., Robin, A., \& Wu, J. S. (2003). Incentives versus standards: properties of accounting income in four East Asian countries. Journal of Accounting and Economics, 36(1), 235-270.

Baydoun, N., \& Willett, R. (2000). Islamic corporate reports. Abacus, 30(1), 7181.

Block, J. H., \& Wagner, M. (2014). The effect of family ownership on different dimensions of corporate social responsibility: Evidence from large US firms. Business Strategy and the Environment, 23(7), 475-492.

Branco, M. C., \& Rodrigues, L. (2008). Social responsibility disclosure: A study of proxies for the public visibility of Portuguese banks. The British Accounting Review, 40(2), 161-181.

Bursa Malaysia. (2007). Corporate Social Responsibility in Malaysian PLCs: 2007 Status Report. Kuala Lumpur, Malaysia.

Campopiano, G., \& De Massis, A. (2015). Corporate social responsibility reporting: A content analysis in family and non-family firms. Journal of Business Ethics, 129(3), 511-534.

Chapple, W., \& Moon, J. (2005). Corporate social responsibility (CSR) in Asia: A seven-country study of CSR web site reporting. Business and Society, 44(4), 415-441.

Chen, S., Chen, X. I. A., \& Cheng, Q. (2008). Do family firms provide more or less voluntary disclosure? Journal of Accounting Research, 46(3), 499-536.

Crane, A., Matten, D., \& Spence, L. J. (2013). Corporate social responsibility in a global context. Chapter in: Crane, A., Matten, D., and Spence, LJ, 'Corporate Social Responsibility: Readings and Cases in a Global Context, 2, 3-26.

Criado-Jimenez, I., Fernandez-Chulian, M., Larrinage-Gonzalez, C., \& HusillosCarques, F. J. (2008). Compliance with mandatory environmental reporting in financial statements: The case of Spain (2001-2003). Journal of Business Ethics, 79(3), 245-262.

El Ghoul, S., Guedhami, O., Wang, H., \& Kwok, C. C. (2016). Family control and corporate social responsibility. Journal of Banking \& Finance, 73, 131146.

Elmogla, M., Cowton, C. J., \& Downs, Y. (2015). Corporate social reporting in Libya: a research note. Social Responsibility Journal, 11(4), 923-932.

Eng, L. L., \& Mak, Y. T. (2003). Corporate governance and voluntary disclosure. Journal of Accounting and Public Policy, 22(4), 325-345.

Feng, F., Sun, Q., \& Tong, W. H. S. (2004). Do government-linked companies underperform? Journal of Banking \& Finance, 28(10), 2461-2492.

Fifka, M. S. (2013). Corporate Responsibility Reporting and its Determinants in Comparative Perspective-a Review of the Empirical Literature and a Meta- analysis. Business Strategy and the Environment, 22(1), 1-35.

Freedman, M., \& Jaggi, B. (2005). Global warming, commitment to the Kyoto protocol, and accounting disclosures by the largest global public firms from polluting industries. The International Journal of Accounting, 40, 215-232. 
Ghazali, N. A. M. (2007). Ownership structure and corporate social responsibility disclosure: some Malaysian evidence. Corporate Governance: The International Journal of Business in Society, 7(3), 251266.

Gugler, P., \& Shi, J. Y. J. (2009). Corporate social responsibility for developing country multinational corporations: Lost war in pertaining global competitiveness. Journal of Business Ethics, 87, 3-24.

Gunardi, A., Febrian, E., \& Herwany, A. (2016). The implication of firmspecific characteristics on disclosure: the case of Indonesia. International Journal of Monetary Economics and Finance, 9(4), 379-387.

Habbash, M. (2016). Corporate governance and corporate social responsibility disclosure: evidence from Saudi Arabia. Social Responsibility Journal, 12(4), 740-754.

Hąbek, P., \& Wolniak, R. (2016). Assessing the quality of corporate social responsibility reports: the case of reporting practices in selected European Union member states. Quality \& Quantity, 50(1), 399-420.

Hackston, D., \& Milne, M. J. (1996). Some determinants of social and environmental disclosures in New Zealand companies. Accounting, Auditing \& Accountability Journal, 9(1), 77-108.

Hahn, R., \& Kuhnen, M. (2013). Determinants of sustainability reporting: a review of results, trends, theory, and opportunities in an expanding field of research. Journal of Cleaner Production, 59, 5-21.

Haniffa, R. M., \& Cooke, T. E. (2005). The impact of culture and governance on corporate social reporting. Journal of Accounting and Public Policy, 24(5), 391-430.

Hasseldine, J., Salama, A., \& Toms, J. (2005). Quantity versus quality: The impact of environmental disclosures on the reputations of UK Plcs. The British Accounting Review, 37(2), 231-248.

Hooks, J., \& Van Staden, C. J. (2011). Evaluating environmental disclosures: The relationship between quality and extent measures. British Accounting Review, 43, 200-213.

Huang, C. L., \& Kung, F. H. (2010). Drivers of environmental disclosure and stakeholder expectation: Evidence from Taiwan. Journal of Business Ethics, 96, 435-451.

Hussainey, K., Elsayed, M., \& Razik, M. A. (2011). Factors affecting corporate social responsibility disclosure in Egypt. Corporate Ownership and Control journal, 1-27.

Jaggi, B., Leung, S., \& Gul, F. (2009). Family control, board independence and earnings management: Evidence based on Hong Kong firms. Journal of Accounting and Public Policy, 28(4), 281-300.

Jenkins, H., \& Yakovleva, N. (2006). Corporate social responsibility in the mining industry: Exploring trends in social and environmental disclosure. Journal of Cleaner Production, 14, 271-284.

Joseph, C., \& Taplin, R. (2011). The measurement of sustainability disclosure: Abundance versus occurence. Accounting Forum, 35, 19-31. 
Kamla, R., Gallhofer, S., \& Haslam, J. (2006). Islam, nature and accounting: Islamic principles and the notion of accounting for the environment. Accounting Forum, 30(3), 245-265.

Khan, H. U. Z., Halabi, A. K., \& Samy, M. (2009). Corporate social responsibility (CSR) reporting: a study of selected banking companies in Bangladesh. Social Responsibility Journal, 5(3), 344-357.

Maali, B., Casson, P., \& Napier, C. (2006). Social reporting by Islamic banks. Abacus, 42(2), 266-289.

Mak, Y. T., \& Li, Y. (2001). Determinants of corporate ownership and board structure: Evidence from Singapore. Journal of Corporate Finance, 7(3), 235-256.

Mangena, M., \& Tauringana, V. (2007). Disclosure, corporate governance and foreign share ownership on the Zimbabwe stock exchange. Journal of International Financial Management and Accounting, 18(2), 53-85.

McGuinness, P. B., Vieito, J. P., \& Wang, M. (2017). The role of board gender and foreign ownership in the CSR performance of Chinese listed firms. Journal of Corporate Finance, 42, 75-99.

Meek, G. K., \& Gray, S. J. (1989). Globalization of stock markets and foreign listing requirements: Voluntary disclosures by Continental European companies listed on the London Stock Exchange. Journal of International Business Studies, 20(2), 315-336.

Michelon, G., Pilonato, S., \& Ricceri, F. (2015). CSR reporting practices and the quality of disclosure: An empirical analysis. Critical Perspectives on Accounting, 33, 59-78.

Murad, W., Islam Molla, R., Mokhtar, M., \& Raquib, A. (2010). Climate change and agricultural growth: an examination of the link in Malaysia. International Journal of Climate Change Strategies and Management, 2(4), 403-417.

Muyibi, S. A., Ambali, A. R., \& Eissa, G. S. (2008). The impact of economic development on water pollution: Trends and policy actions in Malaysia. Water Resources Management, 22(4), 485-508.

Oh, W. Y., Chang, Y. K., \& Martynov, A. (2011). The effect of ownership structure on corporate social responsibility: Empirical evidence from Korea. Journal of Business Ethics, 104, 283-297.

Ortas, E., Gallego Alvarez, I., \& Álvarez Etxeberria, I. (2015). Financial factors influencing the quality of corporate social responsibility and environmental management disclosure: A quantile regression approach. Corporate Social Responsibility and Environmental Management, 22(6), 362-380.

Ousama, A. A., \& Fatima, A. H. (2010). Voluntary disclosure by Shariah approved companies: an exploratory study. Journal of Financial Reporting and Accounting, 8(1), 35-49.

Roberts, R. W. (1992). Determinants of corporate social responsibility disclosure: An application of stakeholder theory. Accounting, Organizations and Society, 17(6), 595-612. 
Said, R., Zainuddin, Y. H., \& Haron, H. (2009). The relationship between corporate social responsibility disclosure and corporate governance characteristics in Malaysian public listed companies. Social Responsibility Journal, 5(2), 212-226.

Sethi, S. P., Martell, T. F., \& Demir, M. (2015). An evaluation of the quality of corporate social responsibility reports by some of the world's largest financial institutions. Journal of Business Ethics, 1-19.

Ullmann, A. A. (1985). Data in search of a theory: A critical examination of the relationships among social performance, social disclosure, and economic performance of US firms. The Academy of Management Review, 10(3), 540557.

Wan-Hussin, W. N. (2009). The impact of family-firm structure and board composition on corporate transparency: Evidence based on segment disclosures in Malaysia. The International Journal of Accounting, 44(4), 313-333.

Zainal, D., Zulkifli, N., \& Saleh, Z. (2013). Corporate social responsibility reporting in Malaysia: A comparison between shariah and non-shariah approved firms. Middle-East Journal of Scientific Research, 15(7), 10351046.

Zulkifli, N. (2012). Social environmental accounting education issues in Malaysia. Kuala Lumpur: University of Malaya Press. 


\section{Appendix: CSRR Index}

\section{Environment}

1. Pollution control/abatement

2. Environmental conservation and repairs

3. Energy conservation

4. Resource conservation and waste management

5. ISO 14001/14004 (Environmental Management System) certification

6. Environmental awards

7. Other commitments towards environmental protection/sustainability

\section{Community}

1. Education

2. Charity

3. Art, culture and heritage

4. Equality in community

5. Youth development and graduate employment programme

6. Employees participation in community service

7. Community health and safety

8. Community and infrastructure support

9. Community awards

10. Community engagement

11. Support for national pride/government sponsored campaigns

\section{Workplace}

1. Employee health and safety (H\&S)

2. Human capital development

3. Workplace diversity and equal opportunity

4. Employee appreciation

5. OHSAS 18001 (Occupational Health and Safety Management Systems)

6. certification

7. Employee relation/engagement

8. Workplace awards

9. Employee remuneration, benefit and assistance

10. Work-life balance

11. Industrial relations

\section{Marketplace}

1. Product development

2. Product/service quality

3. Product/service safety

4. Corporate governance

5. Supplier relation/engagement

6. Customer relation/satisfaction

7. Stakeholder engagement

8. Other stakeholders' matters

9. Marketplace awards

10. Others

11. CSR reporting standard/quality

12. CSR committee

13. Other commitment statements to CSRR 